\author{
Наташа Б. СТАНКОВИЋ ШОШО* \\ Универзитет у Београду \\ Филолошки факултет \\ Катедра за српску књижевност са \\ јужнословенским књижевностима
}

\title{
СРПСКИ РЈЕЧНИК (1818) КАО МЕТОДИЧКА ТЕМА
}

\begin{abstract}
У раду се образлаже на који начин је могуће применити бројна методичка гледишта, корелативне и функционалне методичке радње и поступке у наставном проучавању Српског рјечника (1818) Вука Стефановића Караџића. Сагледава се његова заступљеност у наставним програмима и читанкама за основну школу, указује на адекватну примену методичких гледишта у читању и тумачењу одабраних одломака, као и на уметничке вредности, посебност и сврховитост проучавања Српског рјечника у настави књижевности.

Кључне речи: Српски рјечник (1818), народна књижевност, наставно проучавање у школи.
\end{abstract}

Наставно проучавање Српског рјечника (1818) Вука Стефановића Караџића, омогућује да ученици сагледају његове књижевноуметничке и културноисторијске вредности, као и да доживљајно, сазнајно и истраживачки проуче српско народно стваралаштво објављено у њему (народне лирске песме, шаљиве приче, митолошка, етиолошка и културно-историјска предања и кратке говорне облике).

Вуков Српски рјечник подробније се проучава у основној школи од 2008. године, када је реформисаним наставним програмом предвићено да се поједине одреднице тумаче као секундарни текстови у 5,6 . и 7. разреду ${ }^{20}$ а да се одговарајући одломци као примарни текстови обрађују у 8 . разреду. ${ }^{21}$ Репрезентативни одломци

\footnotetext{
*natasoso06@gmail.com

${ }^{20}$ Реформисан Наставни план и програм за основну школу садржи и бројне научнопопуларне и информативне текстове о животу, веровању и обичајима српског народа. У шестом и седмом разреду предвиђен је избор из Живота и обичаја народа српског Вука Стефановића Караџића. (Видети: Правилник о наставном програму за шести разред основног образовања и васпитања, „Службени гласник Републике Србије - Просветни гласник”, год. LVII - бр. 5/2008, Београд, 26. мај 2008, стр. 2-8; Правилник о наставном програму за седми разред основног образовања и васпитања, „Службени гласник РС - Просветни гласник”, бр. 6/2009 од 10. 06. 2009. године, стр. 2-9).

${ }^{21}$ У читанкама за 8. разред основне школе наводе се одреднице из оба издања Српског рјечника. Међу најзаступљенијима одредницама из првог издања извајају се: икола, Божић, чесница, полажајник, Златоје, бадюак, куга, мора, вила, кукавица, бабине, задужбина, Обил, Богојављење, вјештииа, додоле, женидба, Ивањдан, крсно име, намастир, моба, лазарице, слава.
} 
из првог издања Српског рјечника, као одабрани секундарни, у првом реду књижевнонаучни текстови, заступљени су у читанкама од 5. до 7. разреда основне школе и у уџбеницима се наводе уз одговарајући књижевни текст са којим су у корелативном односу. У табеларном приказу наведене су одреднице из првог издања Српског рјечника које у наставној пракси могу бити реализоване приликом наставног проучавања народне поезије и прозе.

Табела 1.

\begin{tabular}{|c|c|}
\hline Књижевни текст & Одредница из Српског рјечника \\
\hline Вила зида град & Вила (1818: 70) \\
\hline $\begin{array}{l}\text { Војевао Бели Виде, коледо } \\
\text { Грану сунце иза брда } \\
\text { Добар вечер, коледо }\end{array}$ & $\begin{array}{l}\text { Коледа (1818: 521) } \\
\text { Колеђани (1818: 521) } \\
\text { Вид (1818: 69) }\end{array}$ \\
\hline Божић, Божић бата & $\begin{array}{l}\text { Божић (1818: 39) } \\
\text { Батати (1818: 22) }\end{array}$ \\
\hline О јуначе, смиљаниче! & Богојављење (1818: 38) \\
\hline Кој Лазара дарива & $\begin{array}{l}\text { Лазарице (1818: 360) } \\
\text { Лазарева субота (1818: 360) }\end{array}$ \\
\hline Ђурђево ивеће најлепше & Ђурђев дан (1818: 262) \\
\hline Домаћину & Краљице (1818: 335) \\
\hline Иванско ивеће, петровско & Ивањ дан (1818: 237) \\
\hline Нама дода Бога моли & Додоле (1818: 135) \\
\hline Еро с онога свијета & $\begin{array}{l}\text { Кмет (1818: } 314) \\
\text { Када (1818: 291) } \\
\text { Еро (1818: 164) }\end{array}$ \\
\hline Свети Саво & $\begin{array}{l}\text { Вилиндар (1818: 70) } \\
\text { Задужбина (1818: 191) } \\
\text { Ђурђеви стубови/ступови (1818: 162) } \\
\text { Грачаница (1818: 107) }\end{array}$ \\
\hline Три јегуље & Вјештица (1818: 74) \\
\hline $\begin{array}{l}\text { Кад се испроси дјевојка } \\
\text { Кад се надају сватовима код дјевојачке } \\
\text { куће }\end{array}$ & $\begin{array}{l}\text { Женидба }(1818: 368,369,370,371,372) \\
\text { Молитвена чаша }(1818: 410)\end{array}$ \\
\hline Највећа је жалост за братом & $\begin{array}{l}\text { Кукавица (1818: 350) } \\
\text { Тужити (1818: 834) } \\
\text { Задушнице (1818: 192) }\end{array}$ \\
\hline
\end{tabular}




\begin{tabular}{|l|l|}
\hline $\begin{array}{l}\text { Комади од различијех косовскијех пјесама } \\
\text { Цар Лазар и царица Милица } \\
\begin{array}{l}\text { Кмрт Мајке Југовић } \\
\text { Косовка Дјевојка }\end{array}\end{array}$ & $\begin{array}{l}\text { Лазарица (1818: 360) } \\
\text { Видов дан (1818: 65) }\end{array}$ \\
\hline Марко Краљевић укида свадбарину & $\begin{array}{l}\text { Женидба (1818: 368, 369, 370, 371, 372) } \\
\text { Свадбарина (1818: 745) }\end{array}$ \\
\hline & $\begin{array}{l}\text { Вила (1818: 70) } \\
\text { Вјештица (1818: 74) } \\
\text { Корњача (1818: 327) } \\
\text { Кукавица (1818: 745) } \\
\text { Куга (1818: 348) }\end{array}$ \\
\hline Јабланова моба & Моба (1818: 408) \\
\hline Диоба Јакиића & $\begin{array}{l}\text { Молитвена чаша (1818: 410) } \\
\text { Утва (1818: 874) }\end{array}$ \\
\hline
\end{tabular}

Савремена методика наставе књижевности залаже се за афирмацију интерпретативно-аналитичког и проблемско-стваралачког приступа у наставном проучавању (Rosandić 1980: 9), чиме се подстичу и снаже учеников истраживачки, стваралачки и проналазачки однос према књижевноуметничком делу (Николић 2012: 54). Љиљана Бајић указује на значај оспособљавања ученика да у књижевним текстовима откривају „претпостављене начине /деловања и да их стваралачки следе приликом тумачења" (2014: 26).

Локализовање обредних песама помоћу репрезентативних одредница из Cpnског рјечника има мотивациону улогу у наставном процесу. Приликом обраде митолошке песме Вила зида град одредница о вили подстиче заинтересованост ученика за естетске вредности те народне песме. Наставну интерпретацију обредне лирике употпуниће објашњења о празницима (Божић, Богојављење, Васкрсеније, Ђурђевдан, Ивањдан) и аутентичним обредима и народним обичајима (полажајник, бадњак, додоле, лазарице, коледо, краљице). Избор из сватовске лирике може се у наставном проучавању поткрепити вантекстовним објашњењима о женидби, молитвеној чаши, отмици, као и о улози кума у свадбеним обичајима и породици. Корелативним приступом се омогућава да ученици поузданије разумеју народне обичаје, начин живота и породичне вредности наших предака у прошлости. Свака одредница из Српског рјечника доприноси доживљавању, сазнавању и вредновању народне песме уз коју се јавља, репрезентује уметнички свет књижевног дела уз који се наводе и функционално је повезана са њим.

Засноване на начелима довољности и примерена узрасту и знањима ученика, одреднице из Српског рјечника подстичу истраживачку радозналост ученика. Приликом наставног проучавања посленичких народних песама усвајање нових речи (моба, прело, побратим, наджневање) омогућава да ученици постану свесни значаја колективног добровољног рада, солидарности и пожртвованости наших предака у прошлости. 
Снажење свесне активности ученика, путем истраживачке делатности усмерене на свет књижевног дела и на књижевноисторијски контекст, доприноси њиховој бољој припремљености за интерпретацију књижевног текста. Ученици се у истраживачким задацима подстичу да у припремном раду, који се обавља код куће, трагају у Српском рјечнику за значењима мање познатих речи и израза. Њихово истраживање је усмерено према анализи читалачког чина и усвајању књижевнонаучних чињеница. Приликом наставног проучавања народне песме Свети Саво ученици ће разумети значај задужбинарства у песми уколико открију шта су задужбине значиле у прошлости српског народа и какав је био њихов културно-историјски значај. На тај начин ученици богате свој лексички фонд на продуктиван, активан и истраживачки начин.

У методичкој литератури указано је на потребу да се локализовање врши када je ,друштвено-историјска тематика у делу ученицима непозната, а приказана је тако да подразумева читаоце који су о њој довољно обавештени” (Николић 2012: 285).

У првом издању Српског рјечника незнатан је број одредница које указују на историјске чињенице, биографске околности и прототипску стварност. Одредница крвнина (Караџић 1818: 338) доприноси сагледавању историјских околности под којим је српски народ живео док је био под влашћу Турака. Поједине одреднице (село, школа, старјешина, спаија, пандур, намастир) описују друштвено-историјске прилике у прошлости нашег народа. Вантекстовне околности се могу саопштити ученицима при непосредном мотивисању за читање дела, у склопу истраживачких задатака, у уводном излагању и током интерпретације дела. Приликом наставног проучавања епске народне песама Комади од различнијех косовскијех пјесама одреднице Видов дан, Лазарица и Обил из Српског рјечника доприносе „свестраном постављање текста у аутентичне историјске и развојне околности” (Николић, 2012: 284). Вантекстовни подаци о владавини Турака допринеће бољем разумевању народних епских песама средњих (Старина Новак и кнез Богосав, Мали Радојица) и новијих времена (Почетак буне против дахија, Бој на Мишару). Ширим локализовањем народна епска песма се осветљава са временског, просторног, књижевноисторијског, историјско-рецепцијског и поетичког становишта.

Локализовање као методичка радња има мотивацијску улогу у настави, подстиче и развија истраживачке навике и способности ученика и омогућава да они успешније доживе, разумеју и поузданије тумаче и вреднују само дело (Павловић 2008: 105).

Наставник локализовањем текста у надређену целину настоји да прошири сазнања ученика о животу и обичајима српског народа и стваралачком опусу Вука Стефановића Караџића. Припремајући ученике за тумачење народних епских песама новијих времена у осмом разреду, наставник може да локализује текст у стваралачки опус на следећи начин:

- Са Српским рјечником Вука Стефановића Караџића сусретали сте се у досадашњем школовању. Присетите се народних предања о корњачи, мори, вештици, вили и кукавици. - Истакните на који начин су она обогатила ваша сазнања. Образложите који морални прекршај симболизује настанак корњаче. Зашто се баш кукавица везује за губитак брата? Чиме је мотивисано деловање демонолошких бића (виле, вештице, море, куге) према човеку?

Подсећање ученика на занимљиве одреднице које су у претходним разредима обрађивали заинтересоваће их за читање књижевног дела и допринеће њего- 
вом бољем разумевању. Посебно заинтересовани појединци могу, на наставников подстицај, да остваре локализовање на основу информација из Читанке и увида у препоручену секундарну литературу. ${ }^{22}$ Ситуирање текста у временске, просторне и друштвено-историјске оквире, упознавање ученика са битним садржајима, омогућавају ученицима да ваљано доживе, правилно схвате и поузданије тумаче књижевно дело у наставном проучавању.

Уже локализовање се у настави примењује приликом читања и тумачења одломка из Српског рјечника, који се у осмом разреду тумачи као примаран текст. Да би ученици на адекватан начин разумели репрезентативне одломке који се налазе у читанци, неопходно је да их наставник смести у шири контекст дела. Уводним локализовањем се дају сажета обавештења о настанку Српског рјечника и објашњавају појединости у вези са садржином дела. Такво локализовање има информативну и мотивациону улогу у наставном процесу. Наставник може сугестивним излагањем да прочита текст уводног локализовања из читанке и да на тај начин мотивише ученике за тумачење одговарајућег одломка. Уводно локализовање одломака из $C p$ пског рјечника може се остварити на следећи начин:

\footnotetext{
- Вуков Српски рјечник из 1818. године је значајно лексикографско, етнографско и књижевно дело. Речник има обимнију лексикографску грађу, али садржи и низ народних казивања, веровања, прича и предања у функцији тумачења појединих речи. Објашњења многих речи сведоче о начину живота, веровањима, обичајима српског народа. Објављивање Српског рјечника представљао је је први и најважнији корак у стандардизацији српског књижевног језика.
}

Уводно локализовање има за циљ да заинтересује ученике да прочитају дело у целости. Мотивисање и локализовање се у настави врше помоћу подстицајних налога којима наставник настоји да добије објашњења од ученика којима су значења речи позната. Наводимо следеће примере:

- Читајући одломак из Српског рјечника, сазнаћете како је народни колектив доживљавао и славио божићне празнике. Протумачите обредне радње којима се током празничних дана изражава заједништво, благородност и жеља за напретком. Проучите симболику речи приликом обраћања и откривајте њихова могућа значења. Које драгоцене историјске податке сазнајете читајући одредницу школа? Установите какав значај за историју школе и школства има баш та одредница.

Локализовање текста омогућава да се књижевно дело сагледа као саставни део ауторског, друштвеног, историјског, језичког контекста, чиме се остварују важни образовни циљеви - стицање знања о културноисторијском контексту у којем је аутор стварао и одјеку дела у времену у којем се оно појавило. У методичкој литератури се истиче да се различити одломци из секундарне литературе (одабране књижевне критике, одломци из историје књижевности) могу успешно користити у функцији мотивисања и локализовања. Помоћу њих се „и писац и дело могу сврстати у одређену епоху, а наглашавају се и позитивни (а понекад и негативни) естетски судови којима се подстиче проблемски приступ проучавању одабраног дела" (Мркаљ 2011: 74).

\footnotetext{
${ }^{22}$ Ученици се припремају за час на основу Азбучника писаиа у читанци, одабраних одломака из енциклопедија и историја српске књижевности, монографских публикација о животу и раду Вука Стефановића Караџића. Наставник их упућује како да се у секундарној литератури обавесте о значају и вредности пишчевог стваралаштва. Препоручена секундарна литература за ученике: Деретић 1983.
} 
Јован Деретић је указао на изузетност Вуковог Српског рјечника које је драгоцено лексикографског остварење и представља „енциклопедију српског народног живота у којој су описана народна веровања, обичаји, ношња, у којој су унесени исцрпни подаци о нашим крајевима, о друштвеним односима и национално-политичким приликама, о флори и фауни, о просвети и школама, о оружју и оруђу” (Деретић 1983).

Наставник може ученике да упути на самостално трагање за значењима речи у Вуковом речнику, којима ће они откривати истакнуте одлике. Погодне одреднице су: Цариград, Дечани, намастир, мазија, молитва, Пириватра, крсно име, једномесечићи, злогук, Ђаволак, врзино коло, бабине. На основу истраживачког рада ученици ће развијати способност за разумевање фигуративних значења речи и њиховог семантичког диференцирања. Они ће таквим поступањем богатити речник и усавршити своје језичко осећање.

Функционално повезивање наставе књижевности са наставом језика заснива се на уочавању и образлагању експресивних својстава језичких појава у књижевним текстовима који су тумачени на неком од часова који претходи обради, обнављању или систематизацији наставне јединице из језика. У методичкој литератури указано је да се таквим поступањем посебно подстиче мотивисаност и заинтересованост ученика да усвајају нове језичке појаве и постиже да настава српског језика буде занимљивија и продуктивнија (Николић 1979: 282).

Српски рјечник побудиће ученичку радозналост за сазнавање значења мање познатих речи и израза. Наставник ће подстицати ученике да откривају значења речи и израза на основу њиховог састава и контекста у коме су употребљени. Пожељно би било да наставник мотивише ученике да бележе у речнику значења мање познатих речи и да објашњавају њихова значења речима које имају исто или слично значење са њима. Ученици могу речи наводити као синонимске парове: аваз - глас; ага - господар; ада - острво; $а$ дет - обичај; алем - драги камен; ашов - гвоздена лопата; крсно име - слава; злогук - онај што све зло слути; аспида - зла жена. Наставник може да подстакне ученике да самостално осмисле дефиниције за неке лексеме с којима су се сусретали у Српском рјечни$\kappa y$, а које нису објашњене.

Уколико би наставник подстакао ученике да објашњења мање познатих речи пронађу у Речнику српскога језика Матице српске, таквим поступањем активни лексички фонд ученика основне школе био би обогаћен поузданијим објашњењима, а тумачење књижевних дела би било садржајније. Ученици би стекли навику да трагају за могућим значењима речи речи и да их примењују у говору и писању. 
Табела 2. Употреба речника у настави српског језика.

\begin{tabular}{|c|l|l|}
\hline \multicolumn{1}{|c|}{ Реч } & \multicolumn{1}{|c|}{$\begin{array}{c}\text { Значење речи у Српском } \\
\text { рјечнику (1818) }\end{array}$} & $\begin{array}{c}\text { Значење речи у Речнику српскога } \\
\text { језика Матице српске }\end{array}$ \\
\hline срез & $\begin{array}{l}\text { свака кнежина има по неколико среза; } \\
\text { сад у вријеме Црнога Ђорђија звали су } \\
\text { срез оно, докле је заповиједао један ве- } \\
\text { лики буљубаша (капетан) }\end{array}$ & $\begin{array}{l}\text { административно-територијална } \\
\text { јединица која је обухватала више } \\
\text { општина; зграда у којој се налазила } \\
\text { управа такве јединице }\end{array}$ \\
\hline авлија & $\begin{array}{l}\text { улица, велика бела марама коју носе де- } \\
\text { војке кад се удају }\end{array}$ & $\begin{array}{l}\text { двориште } \\
\text { тестија }\end{array}$ \\
\hline
\end{tabular}

Наведени примери показују да ће ученици у појединим случајевима увиђати да су се значења појединих речи током времена променила. Осим тога, ученици ће откривати да у Српском рјечнику постоје речи које се употребљавају у оквиру различитих струка и професија, а данас су ишчезле из употребе или су их замениле неке друге речи.

Табела 3. Употреба речника у настави српског језика.

\begin{tabular}{|l|}
\hline касапин - месар \\
\hline терзија - кројач \\
\hline чаругџија - опанчар \\
\hline чизмешија - чизмар \\
\hline Һурчија - кожуар, крзнар \\
\hline Һарџија - трговац \\
\hline дунђер - дрводеља \\
\hline кадија - судија \\
\hline кујунџија - златар \\
\hline ашчија - кувар \\
\hline бакал - трговац што продаје сир, масло и мед \\
\hline алас - рибар \\
\hline
\end{tabular}

Ученике треба подстицати да речи посматрају у контексту и да у складу са њим дефинишу значење речи. Устаљени вишечлани изрази чије значење ученици откривају у истраживачком раду на речнику могу се примењивати и тумачити у контексту. На пример: Ударио га Винко Лозић. Значење: Опио се. Знања, умења и вештине које су ученици стекли истраживачким, индивидуалним и групним ра- 
дом доприносе богаћењу лексичког фонда ученика. Таквим поступањем посебно се подстиче мотивисаност и заинтересованост ученика да усвајају нове језичке појаве и постиже да настава српског језика и књижевности буде садржајнија и продуктивнија. Увиђањем културноисторијских вредности Српског рјечника, ученици развијају истраживачке способности, читалачке навике и литерарни укус. Тиме се остварују и значајни функционални циљеви - богаћење речника, развијање способности за коришћење примарних, секундарних извора и уџбеника, којима ученици стечено знање проширују и употпуњују.

\section{Лumepamypa}

Бајић Љ. „Читалачке компетенције ученика у савременој настави књижевности.” Савремено изучавање српског језика и књижевности и словенских језика као матерњих, инословенских и страних. Београд: Савез славистичких друштава Србије, 2014.

Деретић Ј. Историја српске књижевности. Београд: Нолит, 1983.

Мркаљ 3. Наставна теорија и пракса 2. Београд: Klett, 2011.

Николић М. Методика наставе српског језика и књижевности. Београд: Завод за уџбенике, 2012.

Николић М. Кьижевно дело у наставној пракси. Београд: Научна књига, 1979.

Павловић М. Припремање наставника и ученика за тумачене књижевних дела. Београд: Завод за уџбенике, 2008.

Павловић М. Спреми се да говориш. Београд: Друштво за српки језик и књижевост, 2014.

Rosandić D. Problemska, stvaralačka i izborna nastava književnosti. Sarajevo: Svjetlost, Zavod za udžbenike, 1980.

Rosandić D. Metodika književnog odgoja. Zagreb: Školska knjiga, 2005.

Наташа Б. Станкович-Шошо

«СЕРБСКИЙ СЛОВАРЬ» (1818) КАК МЕТОДОЛОГИЧЕСКАЯ ТЕМА

Резюме

Применение многочисленных аспектов, коррелятивных и функциональных методологических действий и операций при образовательном изучении „Сербского словаря” (1818) Вука Стефановича Караджича дает возможность функциональной связи преподавания сербского языка и литературы. Исследование показало, что путем корреляции образовательного содержания народной литературы с „Сербским словарем” Вука можно с успехом реализовать образовательные, воспитательные и функциональные цели и задачи сербского языка и литературы, тем самым стимулируется и развивается языковая, творческая и функциональная грамотность учеников.

Ключевые слова: „Сербский словарь” (1818), народная литература, образовательное изучение в школе. 